\title{
Enhancing Students' Learning Activity and Outcomes via Implementation of Problem-based Learning
}

\author{
Noviana Astuti Irna Sakir ${ }^{1}$, Jae Geun Kim ${ }^{1 *}$ \\ ${ }^{1}$ Department of Biology Education, Seoul National University, SOUTH KOREA
}

Received 9 December 2020 - Accepted 17 December 2020

\begin{abstract}
To prove the credibility of empirical and theoretical claims about the ties between problem-based learning (PBL) and educational outcomes, this study investigates the role of PBL as a teaching model to enhance students' learning activities and outcomes in South Sulawesi located in rural Indonesia. The study subjects included first graders at a junior high school who achieved lower levels academically than pupils in other regions. This study involved classroom activities conducted in two cycles, each comprising routine of planning, action, observation, and reflection. Observation sheets and evaluation tests were used to measure students' learning activities and outcomes. The data were subjected to qualitative and quantitative analyses. The results showed that the students' learning activities and outcomes in biology class were improved from the first to the second cycle, suggesting successful resolution of students' difficulties and enhanced performance. In addition, teachers improved their effectiveness by implementing PBL, even though they lacked prior knowledge. Therefore, this study may be useful for practitioners especially teachers administering PBL. PBL is an effective approach that may be incorporated into teaching curriculum by science teachers.
\end{abstract}

Keywords: action research, activities, environment, outcomes, problem-based learning

\section{INTRODUCTION}

Problem Based Learning (PBL) model was developed for medical education and has broadened in applications for other programs of learning, including in science education. It is broadly defined that PBL is a student centered pedagogy in which students are allowed to develop other desirable skills and attributes, not focus on problem solving with a defined solution. In the learning process using PBL also enhanced communication and group collaboration among students. PBL is also defined as a constructivist approach to learning which is believed to promote reflective thinking in students (Bell \& Aldridge, 2014).

Several problems were found at one school in rural area of Indonesia named Bontaramba junior high school, where the students lacked of group collaboration experience in the sense of problem solving in scientific concepts. Originally, students require teachers' assistance in learning and understanding scientific concepts. Biology has a big chance to promote and develop students' communication and group collaboration which provides comprehensive learning experience involving the concepts and processes of science. Biology facilitates understanding of environment and fosters awareness, positive attitudes, scientific temper, values and skills (Desmukh, 2015). Biology is systematized knowledge and enables not only the mastery of scientific facts, concepts, or principles, but also the discovery process. Analysis of environmental issues is an expression of one's love and affection for Mother Earth (Garcia, 2015). As the primary teaching strategy under a teacher-centered approach, direct instruction utilizes passive learning, learning through listening and precise observation. Smith and Smith (2015) emphasized that this can result in superficial knowledge instead of deeper learning, limited practical application, and redundancy. Learning and teaching issues in Indonesia currently involve methods used by instructors in classrooms. Moreover, some studies show that one of the problems in Indonesian education involves lack of teaching skills (Bialangi et al., 2015). Based on observations and interviews conducted with

(c) 2020 by the authors; licensee Modestum. This article is an open access article distributed under the terms and conditions of the Creative Commons Attribution License (http://creativecommons.org/licenses/by/4.0/).

novianaastutiirnasakir@gmail.com $₫$ jaegkim@snu.ac.kr (*Correspondence) 


\section{Contribution to the literature}

- It provides a new learning experience to improve students learning activity and outcomes in rural area.

- The result of this study contributes to the enhancement of biology teachers' knowledge and ability on how to implement PBL model.

- This research can be used as a reference to develop other aspects of PBL model that has not been studied previously.

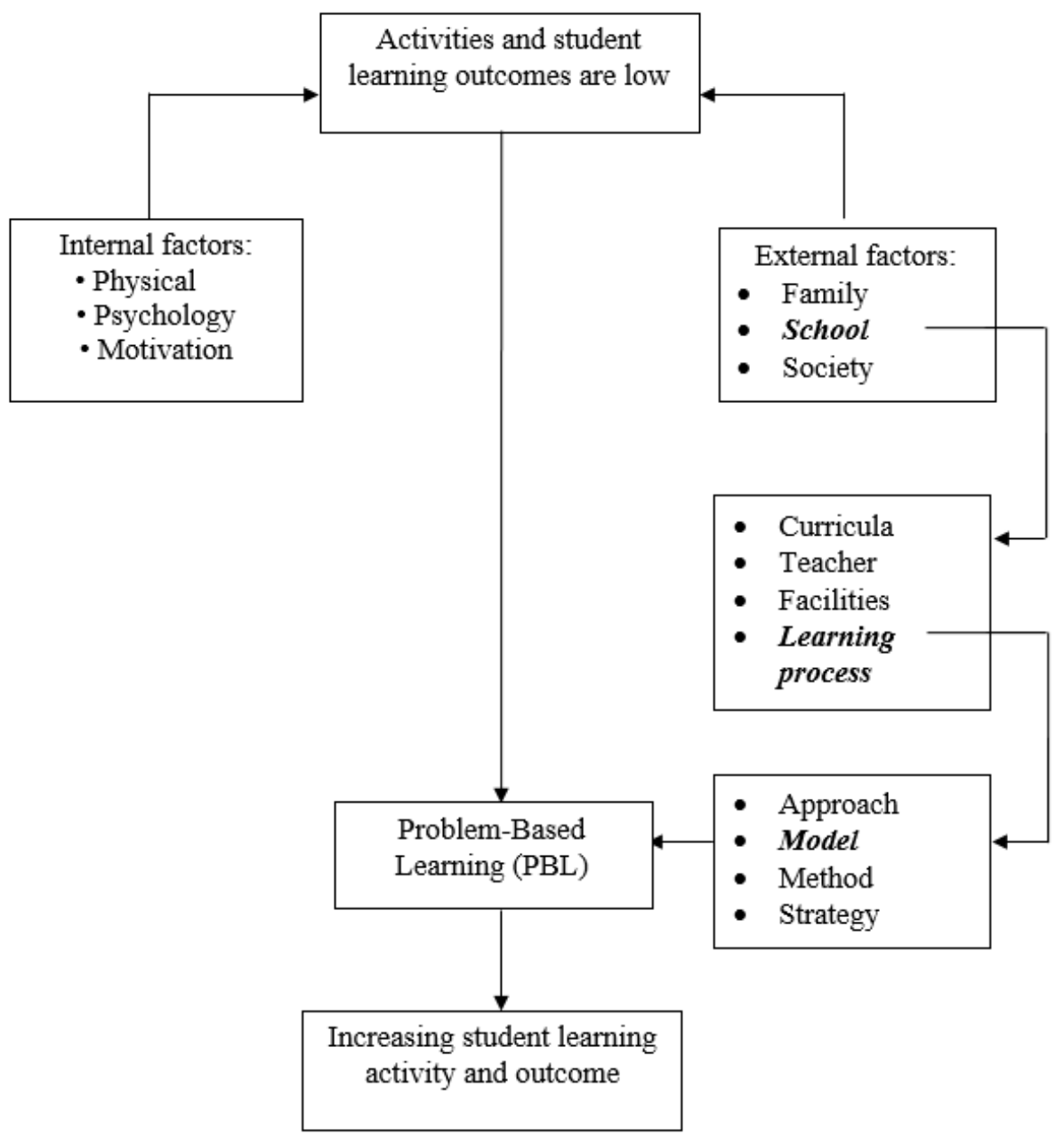

Figure 1. Framework of improving student learning activities and outcomes through PBL implementation

biology teachers at the school mentioned above, it was found that the majority of teachers used direct instructional models more often than other learning models of inquiry leading to boredom and low student learning activities. Furthermore, teacher-centered learning does not lead to optimal learning outcomes among the students. Ramdhani (2014) compared the teacher-centered and student-centered learning strategies and found that the teacher-centered learning did not significantly improve the students' learning outcomes.

The stages involved in implementing the PBL model in this study are planning, action, observation, evaluation, and reflection. These steps are clearly explained in the research procedure. A conceptual framework was developed to represents our research concept and portrays students' activity and outcomes affected by several internal and external factors (Figure 1). However, our study was solely limited to investigating the effects of learning model.

\section{Environmental and Science Education}

Scientific current speaks directly to the relationship between environmental and science education. This current emphasizes a rigorous scientific approach to tackling environmental problems, and identifies cause and effect relationships. The relationship between environmental education and science education is particularly complex. While there have been changes to the rhetoric of what science education practice that many environmental educators seek. The main process is the induction of observation-based hypotheses, and the 
verification of these hypotheses through new observation or experimentation. The approach is predominantly a cognitive one, where the environment is an object of knowledge to be understood in order that appropriate decisions can be made to inform later action. This current imposes the scientific method on the study of environmental realities, in search of an answer or truth as is customary in the science (Erminia, 2014).

Environment is the biggest issue currently. Environmental issues deal with harmful effects of human activity on the biophysical environment. Environmental protection protects natural environment at individual, organizational and governmental levels, for collective benefit (Eccleston \& March, 2010). Therefore, it is important to educate children at school about environmental issues. By implementing PBL, teachers do not present cookie-cutter concepts of pollution and environmental damage, and instead, students are advised to invent their own concepts through problem-solving activities (Barret \& Moore, 2011). PBL encourages students to be more environmentally sensitive and concerned about natural phenomena around them. Additional learning activities enhance the motivation of students to master the subject matter (Maulidiyah et al., 2015).

\section{Problem Based Learning}

One learning model that can be used to overcome this issue is Problem-Based Learning. PBL has been successfully used in other domains, and its benefits have been proved in general (Savery, 2006). PBL provides true experiences that promotes active learning, knowledge building, and natural integration of school learning and real life. This curriculum approach also addresses national standards and integrates disciplines (Torp \& Sage, 2002). The goal of PBL is to help student acquire learning skills and prepare for lifelong learning (Grady et al., 2012). Multiple perspectives provide a comprehensive understanding of the problems and the development of powerful solutions (Walker et al., 2015). PBL provides an opportunity for students to improve their learning activities and outcomes (Geitz et al., 2015). Hence, PBL is not just about the curricular structure (Kek \& Huijser, 2016), but about cognitive and inquisitive skills that students must participate in solving real life problems (Reynolds \& Hancock, 2010).

One of PBL's strengths is to create a problem-solving context in the classroom that realistically reflects the actual problem-solving context in the real life. Thus, the four factors framework is a conceptual tool that helps the teacher structure and deploys (design) a realistic PBL classroom environment. The utility of this tool is sufficiently demonstrated by the use of two completely different courses to design the PBL context (Coombs \& Elden, 2004).
The implementation of problem-based learning model had a positive impact on students' academic performance and their attitudes towards the science course and the application of problem-based learning model had appositive effect on students' conceptual development positively (Akınoğlu \& Tandogan, 2007). Also, a study showed that student attitudes toward science, problem-solving skill and positive views of the learning environment greatly increased (Maria \& Anthony, 2012). The use of PBL also promoted the development of community consciousness in the classroom.

The type of PBL implementation might play a role in learning activity and outcome. Jonassen (2000) analyzed five different types of problem: diagnosis-solution, decision-making, situated case/policy problems, troubleshooting, and design problems. In this research, according to the age of students, a diagnosis-solution type with low to middle complexity of problems was designed. This diagnosis-solution type allows students to collaborate more effectively in the learning process. Environmental issues that become learning topics in this study engaged teacher and students to find available resources to the students in collecting information and diagnosis solution such as textbooks, directly observation, and media mass.

\section{Classroom Action Research}

This study is a classroom intervention that was conducted with the aim of improving the quality of learning practice. Action research is a popular tool for professional development in educational settings (Grundy, 1995) and its purposes are to involve teachers' 'sense of professional role and identity' (Lankshear \& Knobel, 2004) and to improve the teaching quality and practices. In other words, action research focuses practical outcomes and the investigator. Action research is a systematic form of inquiry, which make it possible to collect qualitative and quantitative data (Bryman, 2008; Creswell, 2005; Mills, 2000), and is defended because of its ability to involve participants in the subsequent compilation of diagnosis and problem-solving methods. (Bell \& Aldridge, 2014).

Classroom action research (CAR) is very effective way to improve teaching by assessing misconceptions in the interim period and helping teachers plan the most effective strategies for the rest of the semester (Mettetal, 2001). Classroom action research provides a means of documenting teaching effectiveness. The brief reports and presentations derived as a result of this CAR may be included in portfolios and other reports at the teacher or school level. Moreover, classroom action research can provide new excitement about teaching. Learning classroom action research methodology offers a new challenge, and the results often encourage teachers to change their current strategy. 


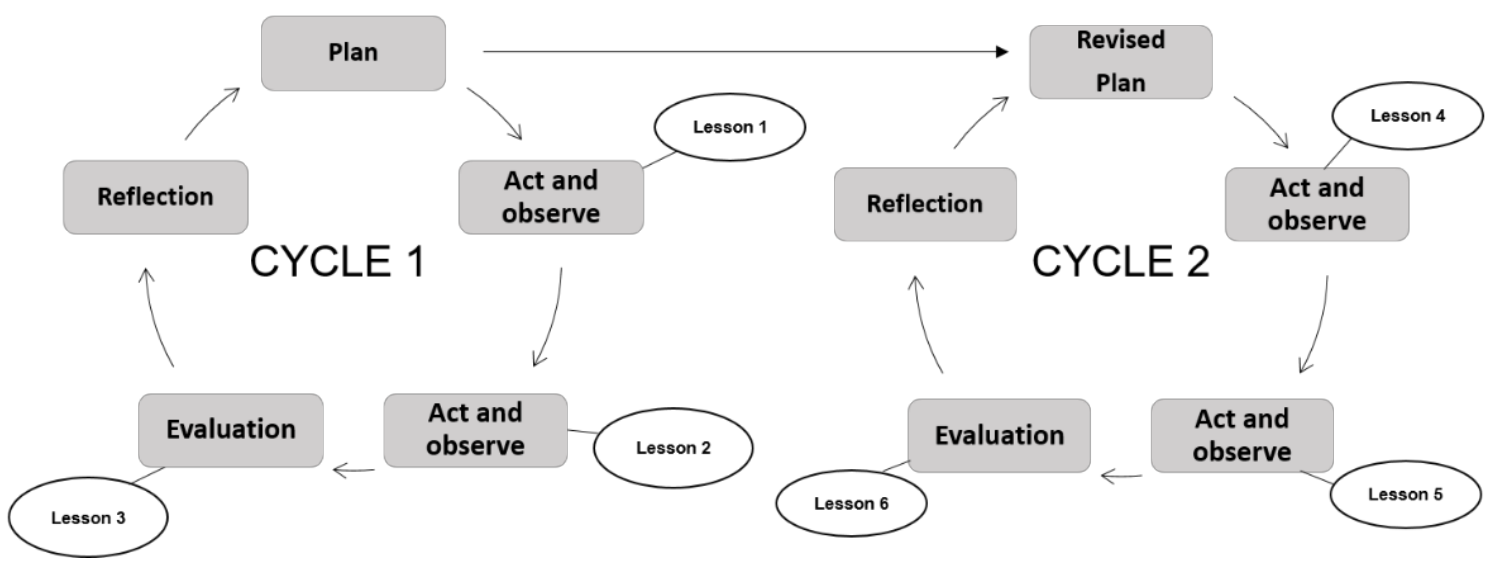

Figure 2. Design of research cycle

\section{Research objectives}

This research aims to promote PBL to be used in science learning process by teachers in the school of rural area in Indonesia, since the background of research school was lack of communication and group collaboration among students in solving science problems (personal observation of Sakir as a biology teacher). This research is conducted to explicitly improve the learning activity and outcome of $7^{\text {th }}$ grade students in Bontoramba junior high school through the implementation of PBL model.

\section{METHOD}

This study was conducted for two months (6 meetings) and based on the school academic calendar, because action research requires several cycles of effective teaching and learning in the classroom. Subjects in this study included 24 students of first grade at Bontoramba junior high school, Jeneponto Regency, South Sulawesi Province, Indonesia.

This classroom action research study was conducted in two cycles referred to as indicators of success. Each cycle consists of two lessons for material delivery and one lesson for evaluation. Therefore, each cycle includes a total of five steps: planning, action, observation, evaluation, and reflection (Figure 2). Each lesson was held for $90 \mathrm{~min}$. The learning topic included environmental management, natural and polluted environment, various sources of environmental pollution, effects of pollution on living beings, and efforts to prevent environmental damage. Furthermore, if the first cycle cannot reach the success indicator, the second cycle was held, which is an improvement of the first cycle.

\section{Research Procedures}

The lesson schedule was organized based on PBL model and steps to implement classroom action research including planning, action, observation, evaluation and reflection.

1. Planning Step

a. Developing learning scenarios by integrating the learning tools such as syllabus, lesson plan, and student worksheet in the PBL model.

b. Preparation of the observation sheet that is used to observe student learning activities.

c. Preparing a written evaluation test (openended) to determine the students' learning outcomes.

2. Action step

Teaching and learning processes in the first and the second cycle were conducted twice. In general, the stages of action in the classroom implemented in the two cycles were as follows:

a. Starting the lessons with greetings, and asking students to pray based on their religion and belief before initiating the learning process;

b. Checking the students' attendance;

c. Phase 1 (problem orientation)

1) Teacher's perception;

2) Teacher asks students to narrate a simple problem involving environmental pollution, followed by a brief description to understand the importance of environmental problem solving.

3) Teacher writes the learning objectives to be achieved on the whiteboard.

4) Teacher conveys the material scope and description of the activities undertaken.

d. Phase 2 (organizing the study program)

1) Teacher prepares the learning materials and media.

2) Teacher helps students to define and organize the tasks related to the problem.

3) Teacher divides the students into five groups.

4) Teacher distributes worksheets related to environmental issues to be discussed. 
5) Teacher directs students in all groups to read the current environmental issues on worksheets and answer the accompanying questions.

e. Phase 3 (individual and group research guide)

1) Teacher assists students in understanding the problems indicated in the worksheet.

2) Teacher leads students to collect appropriate information, read books on material management and environmental pollution as well as various readings from internet or other sources to provide explanations and problem solving.

3) Teacher directs students to express their opinions regarding solutions to solve the problem.

4) Teacher directs students to express their opinions regarding solutions for practical resolution of the problem.

5) Teacher directs students to think of a plan, such as analysis, synthesis, and organization of a plan or idea.

f. Phase 4 (develop and present work)

1) Teacher assists students in planning and preparing reports and posters.

2) Teacher leads students to write down the results of discussion on the answer sheet.

g. Phase 5 (analysis and evaluation of problem solving)

1) Teacher helps students to reflect or evaluate their findings, and corrections via clarification, reinforcement and inference.

2) Teacher asks students to summarize the lessons learned.

3) At the end of the cycle, the students' learning outcomes achieved through PBL implementation are determined via student achievement tests consisting of five problem-solving questions.

3. Observation and Evaluation

The learning process was evaluated by three observers (two science teachers and a researcher) with completing the observation sheets to determine students' activity during the learning process. At the end of each cycle, students were assigned an evaluation to determine the outcomes of their study. Observation data and learning outcome were collected for further analysis.

4. Reflection

Reflection was conducted twice, each executed after the action ended in each cycle. At this stage, the researcher and teachers discussed all the things related to the following steps:
Table 1. School guidelines for the categorization of student learning activities

\begin{tabular}{lc}
\hline Interval values & Activities category \\
\hline $85 \%-100 \%$ & Very active \\
$65 \%-84 \%$ & Active \\
$55 \%-64 \%$ & Quite active \\
$35 \%-54 \%$ & Less active \\
$0 \%-34 \%$ & Not active \\
\hline
\end{tabular}

a. Analysis of action taken to determine its advantages and weakness.

b. Planning further action for students learning and outcome improvements.

c. Drawing conclusions from the obtained data.

\section{Research Instrument}

The research instruments used in this study included observation sheets to measure student activity during the learning process. Observation sheets were arranged based on the guidelines developed by the researchers and validated by two Professors of Biology Education in Makassar State University as expert validators. The observation sheet covered seven main activities including listening, reading, resolving, participating, writing, presenting, and asking. Meanwhile, to measure students' achievement, an open-ended test validated by experts was used.

\section{Data Analysis Technique}

\section{Learning activity}

Students' learning activities were subjected to quantitative and qualitative analysis verbally based on observations during the learning process in each cycle. Each item on the graphs was qualitatived by describing the statistics of students learning activity and outcome. To calculate students' learning activities according to each item, the formula below was used, but referred to the school guidelines to categorize student learning activities (Table 1).

Student activity score $=\frac{\text { total obtained score }}{\text { total activity items }} \times 100 \%$

$$
\begin{gathered}
\text { Percentage of active students per item }= \\
\frac{\text { number of active students }}{\text { total students }} \times 100 \%
\end{gathered}
$$

\section{Learning outcomes}

According to Indonesian Ministry of Education, students' learning outcomes are categorized by schools to measure students' achievements. The formula used to measure students' learning outcomes is provided below, and students' outcomes based on the guidelines of science learning outcomes (Indonesian Ministry of Education, 2002) ranged from 'failed' to 'very good' (Table 2).

Score per question $=\frac{\text { obtained score }}{\text { maximum score }} \times$ question quality 
Table 2. Categorization of science learning outcomes

\begin{tabular}{lc}
\hline Score & Category \\
\hline $86-100$ & Very good \\
$71-85$ & Good \\
$55-70$ & Quite \\
$40-54$ & Less \\
$0-39$ & Failed \\
\hline
\end{tabular}

Table 3. Passing scores

\begin{tabular}{lc}
\hline Score & Category \\
\hline $0-64$ & Incomplete (failed) \\
$65-100$ & Complete (passed) \\
\hline
\end{tabular}

Overall score $=\frac{\sum \text { score per question }}{\text { total question quality }} \times 100 \%$

Average of students score $=\frac{\text { Eoverall score }}{\text { total students }} \times 100 \%$

In this study, the students' learning outcomes were based on the success criteria set by the school (Table 3).

\section{Indicators of success}

This study was considered as a success if:

1. $\geq 70 \%$ of students were active and/or very active.

2. $\geq 70 \%$ of students were good and/or very good.

\section{RESULTS}

\section{Students' Learning Activity}

The study population consisted of 5 groups of firstgrade junior high school students. Four groups consisted of 5 students, and another group included 4 students. The number of students who actively participated in the classroom during PBL implementation based on seven items of learning activity was increased from the first through the second cycle (Figure 3). As shown in Figure
4, the increase in students' activity can be distinguished across seven items of learning activity. All the students engaged in writing activity in the second cycle, followed by listening and reading constituting roughly $90 \%$ of the second and third activities. Meanwhile, the other four activities (resolving, participating, presenting, and asking) were performed by not more than $65 \%$ of the students in the second cycle.

Based on quantitative analysis, the average student's activity in the first cycle was $49.96 \%$, which increased to $71.43 \%$ in the second cycle. The students' learning activities were classified into 5 categories set by the school (Figure 4) The second cycle was conducted as an improvement of the first cycle, which has a positive impact on students' learning activity. Generally, the results were the same as expected. First, the students who listened to teacher's explanation increased in each lesson in the second cycle and were grouped under very active category. Second, the students who read the problem context in the worksheet were also higher in the second cycle and were categorized under very active category. Third, the students who solved problems by providing alternatives and solutions were also included in the active category. Fourth, students who participated in discussion to solve the problem or provided their opinion were included in very active category with the highest percentage $(100 \%)$. Fifth, the students who wrote the answers (addressing given issues) on worksheets also increased in number and were included in the active category. Finally, students who presented their group work and addressed questions to their teacher and other groups were also increased, even though they were included in the less active category. Moreover, the indicators of success were achieved because the percentage of students who reached the very active

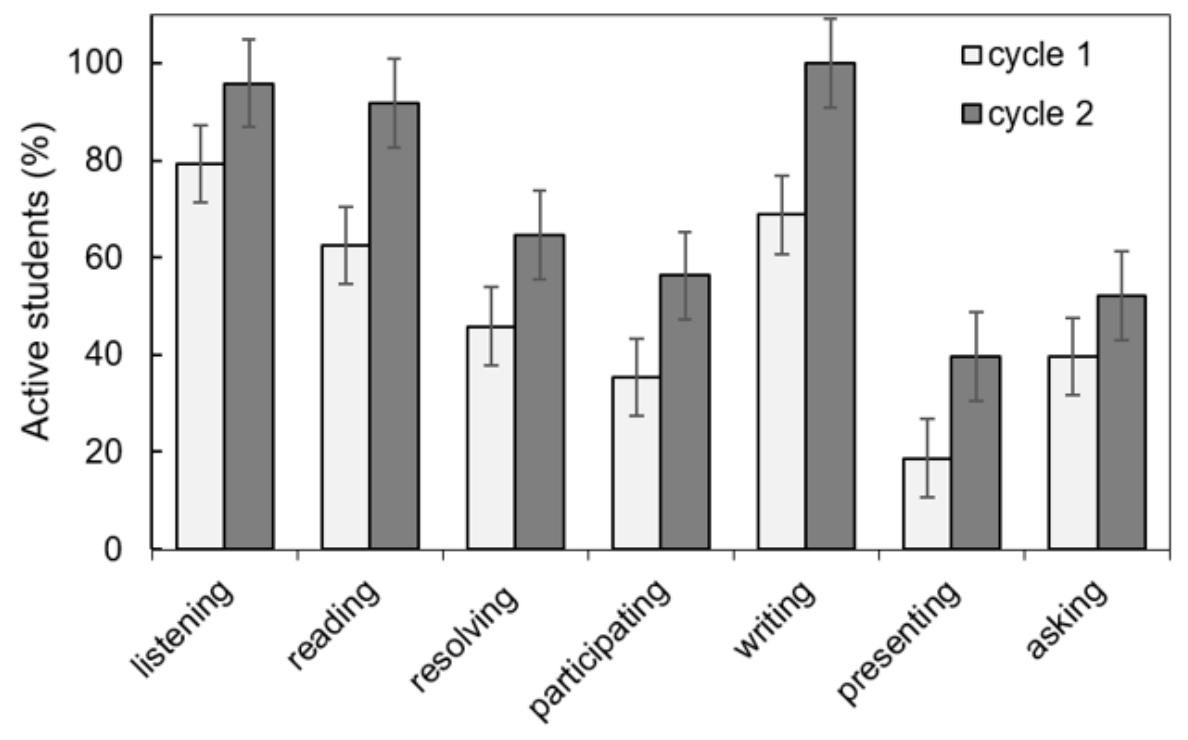

Learning activities

Figure 3. Bar chart (standard error) demonstrating students' activities per item $(\mathrm{n}=24)$ 


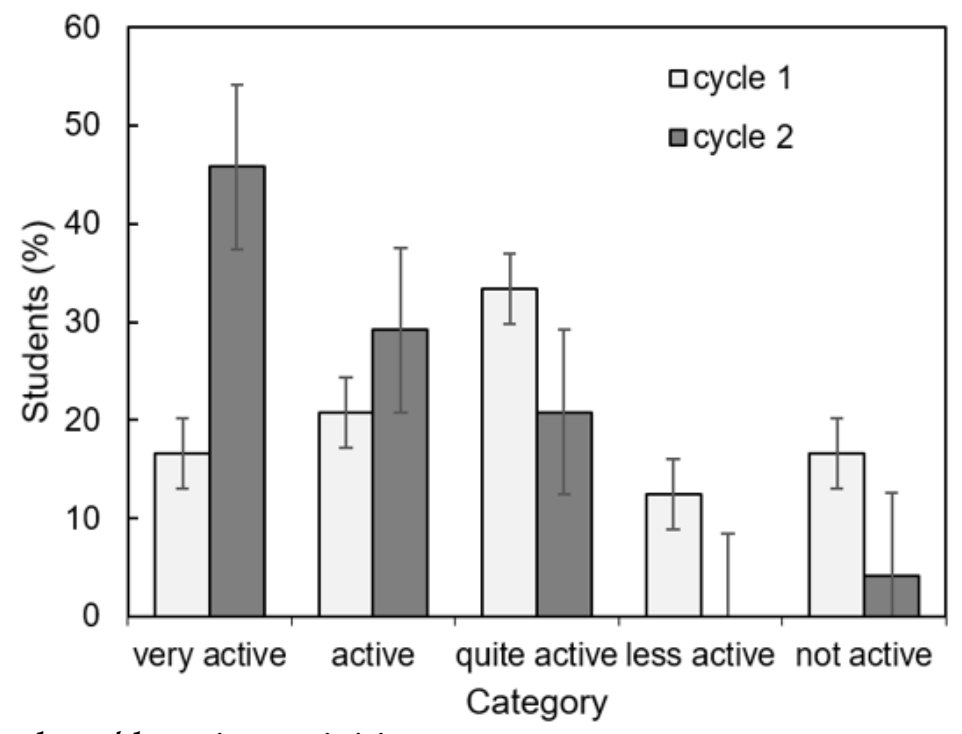

Figure 4. Categories of students' learning activities

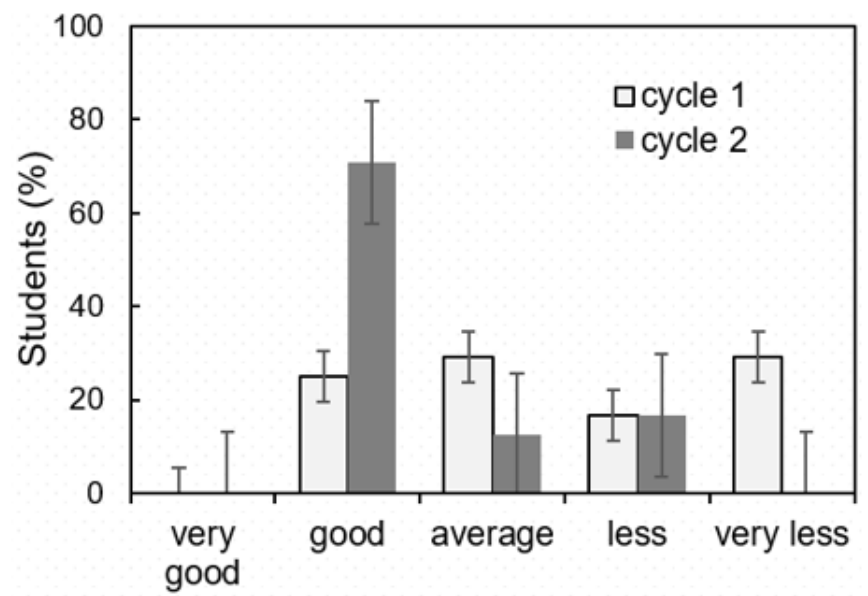

Category

Figure 5. Categorization of learning outcomes

and/or active category exceeded $70 \%$. Accordingly, the average activity of all items achieved by students in the second cycle also increased to $70 \%$.

\section{Students' Learning Outcomes}

The implementation of PBL significantly contributed to increasing the percentage of students with good scores in the examination. Prior to the introduction of PBL, the percentage of students who passed the exams was somewhat low. However, since the PBL was implemented, the number of students who passed the exams and were included in the good category was substantially higher than ever before. The students' scores were grouped into five different categories (Figure 5). Figure 6 presents the students' scores ranging from 40 to 98 out of 100 possible points categorized into very less and good category.

Students' overall satisfaction in the second cycle was better than in the first cycle (Figure 6). The number of students who passed biology subject in pre-action research was less than $50 \%$ of the total students. In the first cycle, approximately $54.17 \%$ of students passed the subject suggesting that the success indicators of classroom action research were not achieved. Nevertheless, in the second cycle, $84 \%$ of students passed the subject. In contrast, the number of students who failed the subject decreased dramatically as seen from the graph, where the success indicator of learning outcomes in the first cycle has yet to be reached. There was a statistically significant difference in the overall scores of the number of students who passed and failed in examinations in the first and second cycles.

\section{Reflection}

\section{Reflection of Cycle I}

Application of PBL in the first cycle as a whole resulted in increased student learning from the first to the second meeting. The average scores obtained did not reach the standard score determined by school (65). Several problems that occurred in the classroom 


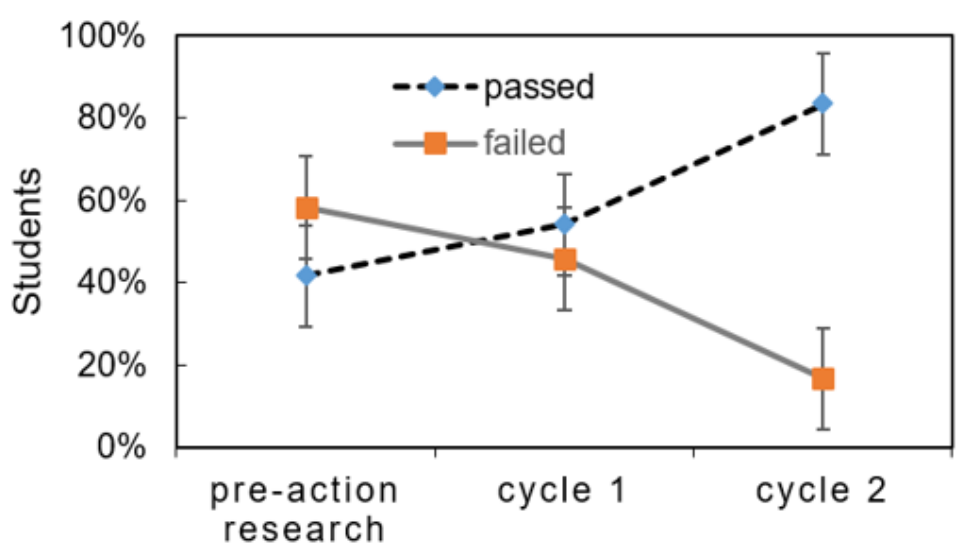

Figure 6. Percentage of passed and failed students

reflected improvement in the second cycle. The challenges found during the learning process were as follows:

1) Students who did not listen to the teacher still existed, which explains the instructions of PBL learning model and information related to the subject matter. At the first meeting of cycle I, students were still not familiar with the new model of learning (PBL) involving previous science learning activities, the teacher simply used a direct teaching method.

2) Several students did not read or examine the context of problems provided on the worksheet.

3) None of the students focused on problem solving. In this case, fewer than $50 \%$ of the total number of students looked for answers on worksheets. Students still did not understand the learning materials, and therefore, it was difficult to find alternatives and solutions related to the context of problems described in worksheet.

4) Students were less active in discussion on cycle I due to lack of cooperation between them caused by divisions among the group members. In other words, the students were clustered together with their close friends in the group. Only a few students expressed their opinion or responded to others. A few male students relied on answers from their female friends. In addition, male students tended to be nosy and interfered with their female friends.

5) Only $35 \%$ of the students wrote the answers on worksheets and failed to use the time as efficiently as possible.

6) The students' learning result was not maximized due to their relatively low activity in the classroom. In addition, students expected a repetition or remedy. After a thorough assessment, only $54.67 \%$ of the students passed the exams, which did not reach the success indicator of learning outcomes defined as $70 \%$ of the total number of students.
Therefore, action in the first cycle was followed by a corrective action in the second cycle. In this case, classroom management was emphasized to facilitate the thought process of problem solving and discussion and improve the learning activity and outcomes. The corrective actions taken in the second cycle were as follows:

1) Initially, the teacher reiterated the PBL model for students and motivated them to be diligent. In addition, teachers were more active in guiding individual students or the group.

2) The teacher separated the members within a group that weakened the discussion. Therefore, it was expected that they focused on discussions in order to resolve problems provided in the worksheet. In addition, teachers also reinforced each group to work in earnest, as a team, and welcome other group friends.

3) The teacher asked students to read and comprehend the problem context provided in the worksheet by utilizing additional studies related to learning materials. In addition, students were asked to be sensitive towards environmental issues to successfully solve the problems presented in the worksheet.

4) The teachers encouraged students to question and respond to their friends, in an effort to enhance students' knowledge.

5) At the time of group discussions, the teacher asked students to examine and fully understand the subject matter and provided written answers on the worksheet.

6) Regarding the number of students who did not reach the standard score, researchers agreed to provide $10 \mathrm{~min}$ for students to review or recall the material studied prior to evaluation.

\section{Reflection of Cycle II}

Second cycle improved the first cycle with a positive impact on student activity. In general, the results were as expected, and increased the students' activity and 
outcomes based on the following findings: (1) increased cooperation between members within group, (2) increased confidence of students to ask, answer, and express opinions to teachers and friends, (3) presentation of working group results by students suggesting review of the material. These results prove that students' understanding of the materials improved. Moreover, the improvement of students' learning activities was consistent with the results of students' learning outcomes. Evaluations at the end of the second cycle showed an increase of students' learning outcomes from the first to the second cycle.

\section{DISCUSSION}

\section{Students Learning Activity}

The results of current study are consistent with previous studies demonstrating that PBL facilitated active learning and enhanced understanding and retention of knowledge. It also helps develop living skills that can be applied to many areas. PBL can be used to increase content knowledge while developing communication, collaboration, critical thinking, problem solving, and self-directed learning skill at the same time. The data show that PBL implementation improves students' learning activities and outcomes. Based on the observations during the learning process, student learning activity increased from the first to the second cycle. Previous studies showed that incorporation of PBL in instruction increased student activity and outcomes. The current study showed similar results with a significant increase in students' outcomes from the first to the second cycle. It suggested that instructors (teachers) should be familiarized with PBL method prior to its implementation. Due to the lack of PBL knowledge and skills, teachers just applied the old teaching methodology (teacher-center learning). Moreover, this strategy should be used continuously to obtain the best result. A proper knowledge or skills of PBL implementation may contribute to enhanced results among the students.

The result of students learning activity shows that PBL makes students to learn during actively participating with meaningful problems. In general, students have more opportunities to form self-directed learning habits, create mental models for learning, and solve problems in a collaborative setting through practice and reflection (Hmelo-Silver, 2004). It was found that the number of students involved in learning activities was positively correlated with the outcomes. The finding that elaborate PBL and action class research constituting the learning phase when the students were asked to deliberate on environmental issues was is in line with previous studies. The combined steps of PBL and CAT may be considered as the best among the other methods or approaches.
All cycles were carried out in 2 months of active learning process. Since the result of learning activity and outcomes were relatively satisfied, the third cycle could not be carried out. Hence, classroom action research was implemented in two cycles. It must be understood that the purpose of PBL is to enable students acquire knowledge in a flexible manner, improve effective problem solving skills, independent learning, collaboration and increased motivation (Hmelo-Silver, 2004). Thus, the teacher in PBL acts as an instructor (tutor), which facilitates students, encouraging, guiding and monitoring the learning process, presents a problem, asks questions, and facilitates investigations or dialogue (Amir, 2009). The context of problem in the worksheets was provided by the teacher, served by a continuation of problems presented by students during discussion in the classroom. A problem cannot be resolved by students alone, but the teacher acts as a facilitator to direct and develop the issue into other related problems.

Various environmental issues in students' worksheet wae presented to encourage students with experimental plans to resolve environmental challenges. The experimental hypotheses in the worksheet could not be implemented due to limited experimental time in the classroom, which limited teachers in formulating a conjecture based on the assigned task. A hypothesis can be proved by observation, experimentation, and literature analysis. However, in this case, the students merely formulated hypotheses and referred to literature review. For example, a student suggested the solution to water pollution by developing an industrial waste management unit such as planting vegetation around the reed waste disposal sites. The plant absorbs toxic substances from the water without affecting the growth of the plant itself. However, such a solution was only based on literature review, and not demonstrated experimentally. Thus, the problem remained as at the conceptual level.

\section{Students' Learning Outcomes}

The outcomes of PBL implementation have shown that it is an effective pedagogical exercise that inherently engages students in active and meaningful learning, resulting in deeper understanding and longer retention (Hung et al., 2003). Student learning outcomes in this study were determined after test or evaluation at the end of cycles 1 and 2, and was analyzed quantitatively and qualitatively. Based on quantitative data analysis, more than $70 \%$ of students were categorized as good achievers in the second cycle, which indicates a dramatic increase of students who were included under good category from the first to the second cycle. Therefore, the PBL model improved students' learning outcomes in the first grade of Bontoramba. Zimmerman (2008) state that motivation is a powerful predictor of students' academic achievement. Depending on individuals' subjective 
intentions, the effect of motivational goals on scholastic achievement varies with the degree of cognitive selfregulation (Covington, 2000). Cognitive self-regulation refers to students' active and intentional engagement in self-learning. Along with learning improvements achieved in the second cycle the increased activity resulted in a positive impact on student learning outcomes. In the second cycle, although students still failed or were incomplete, the majority $(70 \%)$ of students achieved good learning outcomes. The number of students who failed showed a lack of willingness to read the learning material before the evaluation tests.

As the indicators of success were already achieved in the second cycle, the classroom action research did not proceed further to the third cycle. The increasing student learning activity and outcomes revealed a positive impact of the PBL approach, as the students in the classroom were required to seek a solution based on the existing problems in the worksheets. To obtain satisfactory learning results, the teacher stressed that every student write down their individual responses obtained from worksheet, since the problem context reflected the evaluation questions. In addition, students were encouraged to focus more on their surrounding environment by addressing problems related to pollution and environmental damage. The teacher' efforts finally increased student-learning outcomes in the second cycle.

The results significantly favored PBL more than traditional approaches in terms of long-term knowledge retention and this is consistent with the finding of Strobel and Van Barneveld (2009). PBL appears to be an effective strategy to "train competent and skilled practitioners and to promote long-term retention of knowledge and skills acquired during the learning experience" (Yew \& Goh, 2016).

Finally, the authors realized that it is not easy to increase students learning activity and outcomes, especially with the ability of students, which still showed limited understanding and knowledge about environment and its issues. Hence, the key is to improve teaching skills and quality, student management, generate interest and enthusiasm among students before and during the study, encourage submission and responses to questions, and develop critical thinking as well as enhance students' creativity in order to obtained satisfactory results.

\section{CONCLUSION}

Promoting PBL to be used in science learning process by teachers in the school of rural area in Indonesia was successfully applied. Students learning activities and outcomes in biology class were increased after the implementation of PBL model. It can be considered as a success since the research indicators were met, and the percentage of students who experienced increasing learning activities and outcomes constituted more than $70 \%$ of the total number of students.

\section{Educational Implications}

1. Implementation of PBL in this study may be one of the alternatives applicable for science subjects such as biology, especially subtopics that need problem-solving.

2. Application of PBL model to learning activities in schools should be supported by teachers' management skills such that students can focus on learning process.

3. The results of this study need to be corroborated via advanced studies involving different subjects, or even in other fields of interest.

\section{Limitations}

The implementation of PBL in a school located in a rural area, with low student achievements and the teachers' lack of knowledge and teaching skills requires adequate preparation. The implementation of PBL requires teachers with appropriate skill set in handling the learning process that will lead to the improvement of students' learning activities and outcomes. However, in this study general PBL information merely was provided to the teacher before commencing the classroom action research. Therefore, further studies are needed to train the teachers based on comprehensive information related to PBL model.

\section{ACKNOWLEDGEMENTS}

The study was supported by Indonesian Endowment Fund of Education (LPDP) (grant no. 201712120812136).

\section{REFERENCES}

Akınoğlu, O., \& Tandogan, R. O. (2007). The effects of problem-based active learning in science education on students' academic achievement, attitude and concept learning. Eurasia Journal of Mathematics, Science $\mathcal{E}$ Technology Education, 3(1) 71-81. https:/ / doi.org/10.12973/ ejmste/75375

Amir, T. (2009). Inovasi Pendidikan Melalui Problem Based Learning. Jakarta: Prenadamedia Group.

Barrett, T., \& Moore, S. (2011). New Approaches to Problem Based Learning. New York: Taylor \& Francis. https:/ / doi.org/10.4324/9780203846926

Bell, L. M., \& Aldrdge, J. M. (2014). Student Voice, Teacher Action Research and Classroom Improvement. The Netherlands: Sense Publishers.

Bialangi, M. S., Zuabidah, S., Amin, M., \& Gofur, A. (2015). Developmental of students' social attitudes in biology classroom through jigsaw and guided inquiry. International Journal of Academic Research and Development, 1(10), 1-7. 
Bryman, A. (2008). Social Research Methods (3 ${ }^{\text {rd }}$ ed). Oxford: Oxford University Press.

Coombs, D., \& Elden, M. (2004). Introduction to the special issue: problem-based learning as social inquiry- PBL and management education. Journal of Management Education, 28(5), 523-535. https:/ / doi.org/10.1177/1052562904267540

Covington, M. V. (2000). Goal theory, motivation, and school achievement: an integrative review. Annual Reviews in Psychology, 51(1), 171-200. https://doi.org/10.1146/annurev.psych.51.1.171

Creswell, J. (2005). Educational Research: Planning, Conducting, and Evaluating Quantitative and Qualitative Research (2nd edition). New Jersey: Pearson Meril Prentice Hall.

Desmukh, N. D. (2015). Why do school students have misconceptions about life processes? Biology education and research in a changing planet; Selected Papers from the 25 $5^{\text {th }}$ Biennial Asian Association for Biology Education Conference. Kuala Lumpur, Malaysia. https://doi.org/10.1007/978981-287-524-2_4

Eccleston, C. H., \& March, F. (2010). Global Environmental Policy: Concepts, Principles, and Practice. Chapter 7. US: CRC Press. https:/ / doi.org/10.1201/b17375

Erminia, P. (2014). Environmental education and science education: ideology, hegemony, traditional knowledge, and alignment. Revista Brasileira de Pesquisa em Educacao em Ciencias, 14(2), 305-314.

Garcia, L. C. (2015). Environmental science issues for higher-order thinking skills (HOTS) development: a case study in the Philippines. Biology Education and Research in a Changing Planet; Selected Papers from the 25 $5^{\text {th }}$ Biennial Asian Association for Biology Education Conference. Kuala Lumpur, Malaysia. https://doi.org/10.1007/978-981-287-524-2_5

Geitz, G., Brinke, D. J., \& Kirschner, P. A. (2015). Changing learning behavior: self-efficacy and goal orientation in PBL groups in higher education. International Journal of Educational Research, 7(5), 146-158. https:/ / doi.org/10.1016/j.ijer.2015.11.001

Grady, G., Yew, E. H, J., Goh, K. P. L., \& Schmidt, H. G. (2012). One-Day, One-Problem; an Approach to Problem-Based Learning. New York: Springer. https: / / doi.org/10.1007/978-981-4021-75-3

Grundy, S. (1995). Action Research as On-going Professional Development. Perth, Western Australia: Arts Accord Affiliation of Arts Educators (WA).

Hmelo-Silver, C. E. (2004). Problem-based learning: what and how students learn? Educational Psychology Review, 16(3), 235-266. https:/ / doi.org/10.1023/B:EDPR. 0000034022.16470.f3

Hung, W., Bailey, J. H., \& Jonassen, D. H. (2003). Exploring the Tensions of Problem-Based Learning:
Insights from Research. New Directions for Teaching and Learning, 95, 13-23. https://doi.org/10.1002/ tl.108

Jonassen, D. H. (2000). Toward a design theory of problem solving. Educational Technology Research and Development, 48(4), 63-85. https://doi.org/ 10.1007/BF02300500

Kek, M. Y. C. A., \& Huijser, H. (2016). Problem-based Learning into the Future: Imagining an Agile PBL Ecology for Learning. London: University College London. $\quad$ https://doi.org/10.1007/978-981-102454-2

Lankshear, C., \& Knobel, M. (2004). A Handbook for Teacher Research. New York: Open University Press.

Maria, M. F., \& Anthony, R. T. (2012). The impact of problem-based learning (PBL) on student attitudes toward science, problem-solving skills, and sense of community in the classroom. Journal of Classroom Interaction, 47(1), 23-30.

Maulidiyah, G., Sumarni, M., \& Amirudin, A. (2015). Effect of problem-based learning of outdoor study on students outcomes in $9^{\text {th }}$ grade senior high school. Education Journal: Theory, Research, and Development, 3(2), 94-100.

Mettetal, G. (2001). The What, Why and How of Classroom Action Research. The US: Indiana University South Bend.

Mills, G. E. (2000). Action Research: a Guide for Teacher Researcher. Upper Saddle River, NJ: Merrill Prentice Hall.

Ramdhani, M. A. (2014). Comparing teacher-centered learning strategy toward learning outcomes in tariqh subject at junior high school of Muhammadiyah 4 Surakarta. Journal of Islamic Education, 93(3), 223-231.

Reynolds, J. M., \& Hancock, D. R. (2010). Problem-Based Learning in a Higher Education Environmental Biotechnology Course. Singapore: Innovations in Education and Teaching International.

Savery, J. R. (2006). Overview of problem-based learning: definitions and distinctions. Interdisciplinary Journal of Problem Based Learning, 1(4), 9-20. https:/ / doi.org/10.7771/1541-5015.1002

Smith, D., \& Smith, K. (2015). The case for passive learning - the 'silent' community of online learners. European Journal of Open, Distance, and E-learning, $6(3), 45-54$.

Strobel, J., \& van Barneveld, A. (2009). When is PBL more effective? A meta-analyses comparing PBL to conventional classrooms. Interdisciplinary Journal Problem-Based Learn, 3(1), 4-10. https://doi.org/ 10.7771/1541-5015.1046

Torp, L., \& Sage, S. (2002). Problems as Possibilities; Problem-Based Learning for K-16 Education (2 ${ }^{\text {nd }}$ 
Edition). USA: Association for supervision and curriculum development.

Walker, A., Leary, H., Cindy, E., Hmelo-Silver, C. E., \& Ertmer, P. A. (2015). Essential Readings in ProblemBased Learning, Exploring and Extending the Legacy of Howard S. Barrows. USA: Purdue University Press. https://doi.org/10.2307/j.ctt6wq6fh.25

Yew, E. H. J., \& Goh, K. (2016). Problem-based learning: An overview of its process and impact on learning.
Health Professions Education, 2(2), 75-79. https:/ / doi.org/10.1016/j.hpe.2016.01.004

Zimmerman, B. J. (2008). Investigating self-regulation and motivation: historical background, methodological developments, and future prospects. American Educational Research Journal, 45(1), 166-183. http://doi.org/10.3102/000283120 7312909

\section{http://www.ejmste.com}

